Discussion Paper No. 12-065

Mitigating Market Power under Tradeable Permits

Peter Heindl

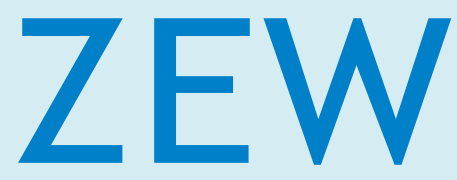

Zentrum für Europäische Wirtschaftsforschung $\mathrm{GmbH}$

Centre for European Economic Research 
Discussion Paper No. 12-065

\title{
Mitigating Market Power under Tradeable Permits
}

\author{
Peter Heindl
}

Download this ZEW Discussion Paper from our ftp server:

http://ftp.zew.de/pub/zew-docs/dp/dp12065.pdf

Die Discussion Papers dienen einer möglichst schnellen Verbreitung von neueren Forschungsarbeiten des ZEW. Die Beiträge liegen in alleiniger Verantwortung der Autoren und stellen nicht notwendigerweise die Meinung des ZEW dar.

Discussion Papers are intended to make results of ZEW research promptly available to other economists in order to encourage discussion and suggestions for revisions. The authors are solely responsible for the contents which do not necessarily represent the opinion of the ZEW. 


\section{Das Wichtigste in Kürze}

Wie durch R. Hahn (1984) gezeigt wurde, kann Marktmacht eines Unternehmens auf einem Markt für handelbare Eigentumsrechte und daraus resultierende Wohlfahrtsverluste dadurch gemindert werden, dass dem Unternehmen freie Allokation an Emissionsrechten in vollem Umfang zugewiesen wird. In diesem Arbeitspapier wird ein alternativer Ansatz zur Linderung von Marktmacht vorgeschlagen. Falls eine Regulierungsbehörde nicht die volle Menge an Zertifikaten an ein Unternehmen mit Marktmacht frei zuteilen kann oder möchte, kann sie alternativ die globale Emissionsbegrenzung (cap) anpassen um die Ausübung der Marktmacht zu unterbinden. Durch Anpassung des caps kann ein Zustand erreicht werden in dem das Unternehmen mit Marktmacht einen Preis wählen wird, der dem Preis unter vollständigem Wettbewerb entspricht. Als Ergebnis daraus kommt es zu einer Angleichung der Grenzvermeidungskosten der regulierten Unternehmen und das Regulierungsziel kann zu geringstmöglichen Kosten erreicht werden.

Falls der cap effizient gewählt wurde, so dass Grenznutzen und Grenzkosten der Regulierung angeglichen sind, wird eine Änderung des caps zu einem Verlust an sozialer Wohlfahrt führen. Um diesen Effekt zu kontrollieren, wird der Schaden einer Änderung des caps mit dem Nutzen der Begrenzung von Marktmacht abgewogen. Dadurch wird eine zweibeste Lösung als Reaktion auf Marktmacht in Märkten für handelbare Eigentumsrechte für den Fall abgeleitet, dass das Regulierungsziel ein soziales Optimum darstellt.

\section{Non-Technical Summary}

As shown by R. Hahn (1984), free allocation to a firm with market power equal to the amount of permits the firm uses in a competitive equilibrium can prevent welfare losses under market power. In this paper an alternative option to mitigate market power is proposed. If the regulating authority is unwilling or unable to hand out 'full' free allocation to a firm with market power, it may alternatively alter the economy wide emissions constraint (cap). Changing the cap can lead to a situation where the firm with market power will choose a price similar to the competitive equilibrium. As a consequence, marginal abatement costs of regulated firms are equated and the least cost solution is achieved.

If the cap is chosen efficiently, so that marginal benefits and marginal costs of regulation are equated, changing the cap may decrease social welfare. To account for this effect, marginal social damages from changing the cap are balanced to marginal gains from mitigating market power. By doing so, a second-best solution to mitigate market power in permit markets is derived. 


\title{
Mitigating Market Power under Tradeable Permits
}

\author{
Peter Heindl*
}

October 8, 2012

\begin{abstract}
As shown by R. Hahn [6], free allocation equal to the amount of permits a firm with market power uses in equilibrium, can prevent welfare losses. If the necessary amount of free allocation is not provided to the firm with market power, a second best solution is obtained where marginal abatement costs of regulated firms are not equated. In this paper, it is proposed that the government may change the economy wide emissions constraint (cap) as a response to market power, e.g. when free allocation cannot be adjusted. Changing the cap can lead to a situation where marginal abatement costs are equated in the presence of market power. Because changing the cap will lead to changes of social welfare, both effects must be balanced. It is shown that there exists a second best social optimum by balancing the positive effect of limiting market power and the negative effect of changing the cap.
\end{abstract}

Keywords: Tradeable Permits; Market Power; Environmental Regulation JEL-Classification: Q53; L12; D21

\section{Introduction}

As argued by Hahn [6] and generally believed in the literature, adjusting the free allocation of a firm with market power under tradeable permits is the only way to eliminate negative impacts (i.e. welfare losses) of market power in permit markets. Using a two-firm model with a dominant firm and a price taking firm, where firms have explicit unrestricted emissions (emissions without regulation), it is shown in this paper that by adjusting the overall emissions constraint (cap), market power can be eliminated. The model is also able to reproduce the result of Hahn [6], that by adjusting free allocation of the dominant firm, market power can be eliminated. If the overall emissions constraint (cap) was chosen optimally, i.e. so that overall marginal control costs and overall benefits from regulating the externality are equated, adjusting the cap will decrease social welfare. To account for this effect, the negative consequences of adjusting the cap are balanced by the positive effect of mitigating market power. Given an optimal choice of the overall emissions constraint (cap), adjusting the cap can never deliver a first-best solution. Therefore, adjusting the free allocation is the only efficient way to eliminate negative impacts (i.e. welfare losses) of market power. However, by changing the cap a second-best solution could be obtained, e.g. if policy makers are unable or unwilling to hand out full free allocation to a firm with market power.

*Centre for European Economic Research L7,1; D-68161 Mannheim, Germany; Email: heindl@zew.de This research benefited from support by the Scientific Advisory Council of the Centre for European Economic Research; such support does not imply agreement with the views expressed in the paper. All errors are solely mine. 


\section{The Model}

As described by Hahn [6] and in a similar way by Sinn \& Schmoltzi [14], polluters may have market power in the permit market. While price taking firms minimize costs under regulation subject to the quantity of abatement (or quantity of emissions), firms with market power minimize costs subject to the permit price. In contrast to Malik [10], firms are compliant ${ }^{1}$. Assuming a simple abatement cost function, the model of Hahn [6] can be described in a simple two-firm setup.

Abatement costs for firm $i$ are dependent on the quantity of abatement $q_{i} \geq 0$ and technical abatement $\operatorname{costs} \alpha_{i}>0$. Abatement costs are given by

$$
c_{i}=\frac{1}{2} \alpha_{i} q_{i}^{2} .
$$

Firm 1 has power on the permit market while firm 2 is a price-taker. Firm 2 minimizes costs by choosing a quantity of abatement $q_{2}$ given the observed permit price $p$. Each firm's unconstrained emissions are $q_{0 i}$ and freely allocated permits are $a_{i}$. Firm 2 minimizes costs $C_{2}$ by solving the problem

$$
\min _{q_{2}}\left[\frac{1}{2} \alpha_{2} q_{2}^{2}+p\left(q_{02}-q_{2}-a_{2}\right)\right] .
$$

Equating marginal abatement costs to the price per unit output yields the optimal quantity of abatement of firm 2. The price-taking firm's reaction function to the permit price is given by

$$
q_{2}=\frac{p}{\alpha_{2}} .
$$

Firm 1 has power on the permit market and chooses a permit price that minimizes costs given the reaction of firm 2 and given that the overall quantity constraint $Q$ is met. Firm 1 faces the problem

$$
\begin{gathered}
\min _{p}\left[\frac{1}{2} \alpha_{1} q_{1}^{2}+p\left(q_{01}-q_{1}-a_{1}\right)\right] \\
\text { s.t. } \quad q_{1}=q_{01}+q_{02}-q_{2}-Q .
\end{gathered}
$$

Substituting (5) into (4) yields firm 1's overall costs given its market power

$$
\hat{C}_{1}=\frac{1}{2} \alpha_{1}\left(q_{01}+q_{02}-\frac{p}{\alpha_{2}}-Q\right)^{2}+p\left(q_{01}-\left(q_{01}+q_{02}-\frac{p}{\alpha_{2}}-Q\right)-a_{1}\right) .
$$

Deriving for $p$, equating to zero, and resolving for $\mathrm{p}$ yields the price firm 1 will choose under market power

$$
\hat{p}=\frac{\alpha_{2}\left(\left(q_{01}+q_{02}\right) \alpha_{1}+\left(a_{1}+q_{02}\right) \alpha_{2}-Q\left(\alpha_{1}+\alpha_{2}\right)\right)}{\alpha_{1}+2 \alpha_{2}} .
$$

\footnotetext{
${ }^{1}$ This implies that there is no cheating and non-compliance, because a) firms are properly monitored so that all emissions are reported and $b$ ) firms surrender permits equal to the amount of emissions.
} 
Firm 2 as price taker generates abatement $\hat{q}_{2}$

$$
\hat{q}_{2}=\frac{\hat{p}}{\alpha_{2}} .
$$

Firm 1 delivers the abatement volume $\hat{q}_{1}$ that is required to meet $Q=\hat{q}_{1}+\hat{q}_{2}$.

If there was no market power, both firms would equate marginal abatement costs. Under the condition that the overall quantity constraint $Q$ must be met, the price in a competitive setup would be

$$
p^{*}=\frac{Q \alpha_{1} \alpha_{2}}{\alpha_{1}+\alpha_{2}} .
$$

Corresponding abatement volumes (if there is no market power) are given by

$$
\begin{aligned}
& q_{1}^{*}=\frac{Q \alpha_{2}}{\alpha_{1}+\alpha_{2}} \\
& q_{2}^{*}=\frac{Q \alpha_{1}}{\alpha_{1}+\alpha_{2}} .
\end{aligned}
$$

A third party with zero emissions owns a number of $A=Q-a_{1}-a_{2}$ permits, sells the entire contingent $A$ to the market and behaves as price taker. The third parties revenues are

$$
R=A p .
$$

Total costs are aggregated technical abatement costs and can be expressed as

$$
C=C_{1}+C_{2}-R
$$

The simple model is able to reproduce the results of Hahn [6]. The price under market power $\hat{p}$ will be lower (higher) than the competitive price $p^{*}$ if firm 1 receives less (more) permits for free than it needs for compliance. The price under market power is equal to the price in a competitive situation if the amount of freely allocated permits to firm 1 equals $q_{1}^{*}$.

Figure 1 shows the consequences of market power on permit markets. Assuming that revenues $R$ raised by the third party are redistributed so that it leaves the costs of producing $Q$ unaffected, the resulting welfare loss under market power and a manipulated price of $\hat{p}$ is $\mathrm{CDF}$ compared to the first best case without market power where marginal abatement costs are equated at price $p^{*}$ in point $C$.

\section{Economic Efficiency and Market Power}

Hahn [6] has claimed that 'the only case in which the marginal cost of abatement will equal the equilibrium price is when firm 1's distribution of permits just equals the amount it chooses to use' and that it is necessary 'to pick an initial distribution of permits for firm 1 which coincides with the cost-minimizing solution' to avoid negative consequences of market power. However, in the model presented above, there exists a set of possible situations where market power cannot be exerted successfully. To identify these sets, the cost minimizing price under perfect competition $p^{*}$ is equated to the price under market power $\hat{p}$. If the government is 


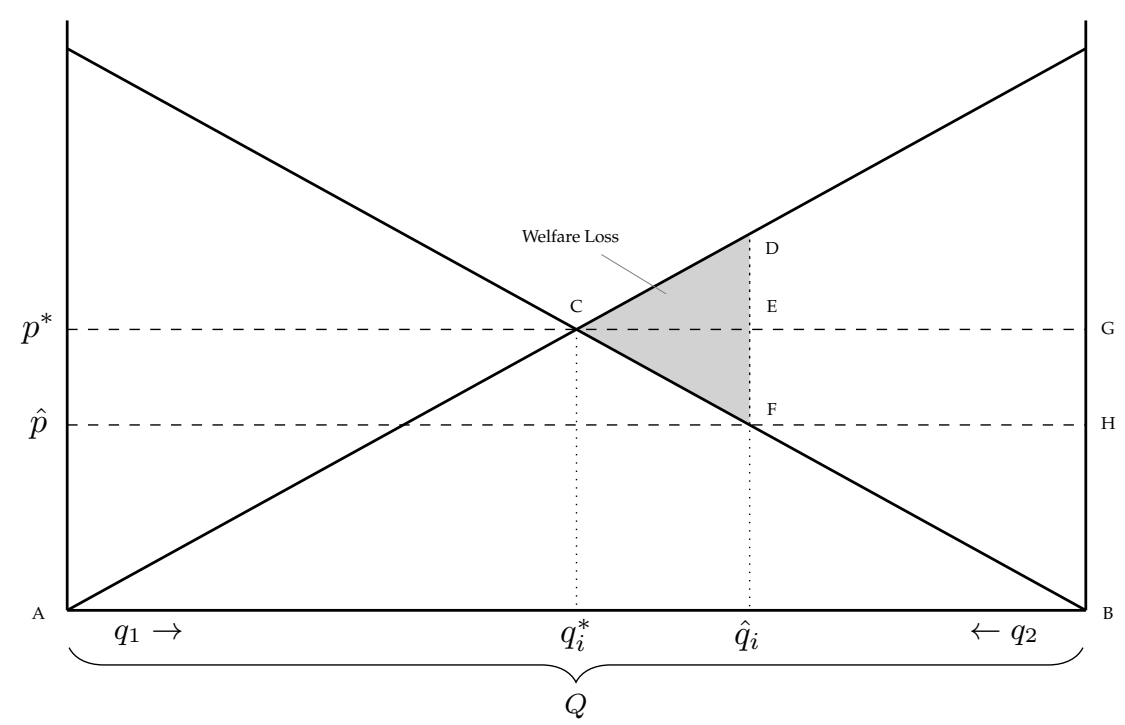

Figure 1: Welfare consequences of market power assuming that the firm with market power receives less permit for free than it needs for compliance and, as a consequence, chooses to set a price $\hat{p}<p^{*}$.

able to choose one ore more variables in Equation (9) and (7) exogenously, it might be able to detain firm 1 from exerting its market power.

$$
\frac{Q \alpha_{1} \alpha_{2}}{\alpha_{1}+\alpha_{2}}=\frac{\alpha_{2}\left(\left(q_{01}+q_{02}\right) \alpha_{1}+\left(a_{1}+q_{02}\right) \alpha_{2}-Q\left(\alpha_{1}+\alpha_{2}\right)\right)}{\alpha_{1}+2 \alpha_{2}} .
$$

Assuming that the government is unable to influence (private) abatement $\operatorname{costs} \alpha_{i}$ or unrestricted emissions $q_{0 i}$ without generating considerable private costs (e.g. by restricting firm $i$ 's output) or public expenditures (e.g. by R\&D subsidies), the only remaining option is an adjustment of the economy wide emissions constraint $Q$. Solving (14) for $Q$ yields

$$
\bar{Q}=\frac{\left(\alpha_{1}+\alpha_{2}\right)\left(\left(q_{01}+q_{02}\right) \alpha_{1}+\left(a_{1}+q_{02}\right) \alpha_{2}\right)}{2 \alpha_{1}^{2}+4 \alpha_{1} \alpha_{2}+\alpha_{2}^{2}} .
$$

The model properties regarding free allocation as described by Hahn [6] and others can be reproduced by solving (14) for $a_{1}$

$$
\bar{a}_{1}=Q-q_{02}+\frac{\left(2 Q-q_{01}-q_{02}\right) \alpha_{1}}{\alpha_{2}}+\frac{Q \alpha_{1}}{\alpha_{1}+\alpha_{2}} .
$$

Equation (16) shows that if the regulating authority has chosen free allocation to the firm with market power so that it minimizes or removes market power and the regulating authority changes the overall cap, it also has to adjust free allocation to the firm with market power.

The assumption of perfect markets for permits and final goods is not an innocent one as a large body of literature confirms. Apart of market power, transaction costs [15, 7] and asymmetric information can lead to situations where the final allocation of abatement efforts is not independent from free allocation. Also power in markets for final goods can lead to distortions in the permit market. As Hintermann [9] has shown, permit allocation even below the one proposed by Hahn [6] may lead to negative consequences on permit markets 


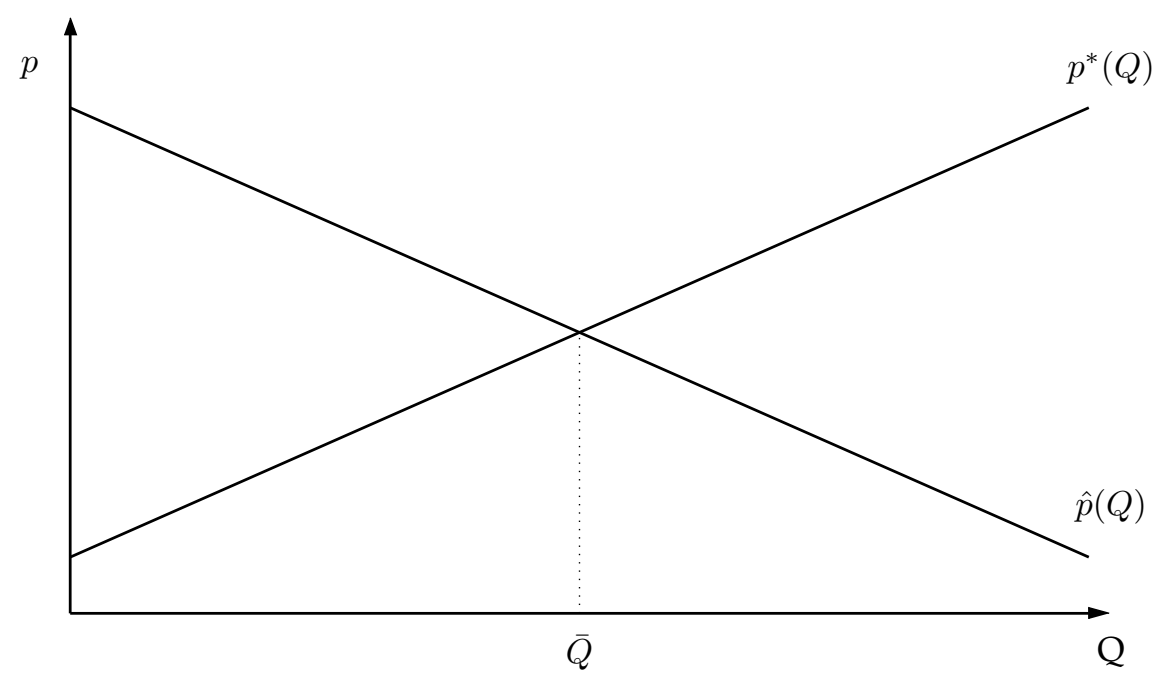

Figure 2: Competitive price and price under market power dependent on the overall emissions restriction $Q$ for given values of $\alpha_{i}, q_{0, i}$, and $a_{1}$. The competitive price $p^{*}(Q)$ is generally upward sloping in $Q$, while the price under market power $\hat{p}(Q)$ is generally downward sloping.

when power on markets for final goods is considered. Even if perfect markets are assumed, governments may carefully use the instrument of free allocation because of resulting welfare transfers from consumers to producers, also called windfall profits [2, 16, 5, 8]. Dependent on the principles that allocation decisions are based on, the risk of generating perverse incentives for regulated firms might exist [12]. Free allocation further decreases the options for revenue recycling (e.g. lowering existing taxes and decrease deadweight losses) and may have negative welfare consequences [4, 13, 3].

When adjusting $a_{1}$ appears to be an problematic choice to impede firm 1 from exerting market power, adjusting $Q$ could be an alternative option. Under the assumption that $Q$ is an optimal choice by the social planer, increasing or decreasing $Q$ would reduce social welfare by increasing negative impacts from external effects on the society while in the same time social welfare is increased by the reduced capability of firm 1 to exert market power.

A marginal benefit function (MAB) similar as in Mandell [11] is assumed, with $f$ as a positive constant and $-g$ as the marginal rate in which the damage from emitting $q_{01}+q_{02}$ is reduced

$$
\mathrm{MAB}=f-g Q
$$

Pareto efficiency would be achieved if MAB are equated to aggregated marginal costs (MAC). Aggregated costs (for the case without market power) are derived by substituting (10) and (11) into (1) for $i=1,2$ and summing up both terms

$$
c_{1}+c_{2}=\frac{Q^{2} \alpha_{1} \alpha_{2}}{\alpha_{1}+\alpha_{2}} .
$$


Deriving by $Q$ yields the aggregated MAC, which coincides with (9) because $p^{*}$ equals the MAC in the least costs case [1]. Since it represents aggregated marginal costs in the absence of market power it is labeled with a asterisk

$$
\mathrm{MAC}^{*}=\frac{Q \alpha_{1} \alpha_{2}}{\alpha_{1}+\alpha_{2}} .
$$

Equating $\mathrm{MAC}^{*}$ and $\mathrm{MAB}$ and resolving for $Q$ yields the social optimal amount of aggregated abatement $Q^{*}$

$$
Q^{*}=-\frac{f\left(\alpha_{1}+\alpha_{2}\right)}{g \alpha_{1}+g \alpha_{2}-\alpha_{1} \alpha_{2}} .
$$

By changing $Q$, two types of effects occur. First, the price under market power $\hat{p}$ moves closer to a price $p^{*}$ as $Q$ goes to $\bar{Q}$ (Eq. 15). Second, as $Q$ goes to $\bar{Q}$ it may move further away from the social optimal level $Q^{*}$. While the first effect increases welfare by weakening market power the second effect decreases welfare for obvious reasons. A 'second best' social optimum under market power is achieved where marginal welfare increases from the first effect equal marginal welfare decreases from the second effect.

The damage caused by market power when choosing a certain $Q$ is

$$
\begin{gathered}
\mathrm{DM}=\left(\int_{0}^{q_{1}^{*}} c_{1}^{\prime} \mathrm{d} q_{1}+\int_{0}^{q_{2}^{*}} c_{2}^{\prime} \mathrm{d} q_{2}\right)-\left(\int_{0}^{q_{1}} c_{1}^{\prime} \mathrm{d} q_{1}+\int_{0}^{q_{2}} c_{2}^{\prime} \mathrm{d} q_{2}\right) \\
\mathrm{DM}=\frac{1}{2}\left(-q_{1}^{2} \alpha_{1}-q_{2}^{2} \alpha_{2}+\alpha_{1}\left(q_{1}^{*}\right)^{2}+\alpha_{2}\left(q_{2}^{*}\right)^{2}\right) .
\end{gathered}
$$

Substituting $q_{i}^{*}$ and $\hat{q}_{i}$ into (22), deriving for $Q$, equating to zero and solving for $Q$ yields the marginal damage from market power for changes of $Q$

$$
\begin{aligned}
\mathrm{MDM} & =\frac{\left(\left(q_{01}+q_{02}\right) \alpha_{1}+\left(a_{1}+q_{02}\right) \alpha_{2}\right)\left(\alpha_{1}^{2}+3 \alpha_{1} \alpha_{2}+3 \alpha_{2}^{2}\right)}{\left(\alpha_{1}+2 \alpha_{2}\right)^{2}} \\
& +\quad \frac{Q\left(-\alpha_{1}^{2}-3 \alpha_{1} \alpha_{2}-3 \alpha_{2}^{2}\right)\left(\alpha_{1}^{2}+3 \alpha_{1} \alpha_{2}+3 \alpha_{2}^{2}\right)}{\left(\alpha_{1}+\alpha_{2}\right)\left(\alpha_{1}+2 \alpha_{2}\right)^{2}} .
\end{aligned}
$$

The damage caused by moving away from the pareto efficient volume of abatement is

$$
\begin{gathered}
\mathrm{DP}=\int_{Q}^{Q^{*}} \operatorname{MAB} \mathrm{d} Q-\int_{Q}^{Q^{*}} \operatorname{MAC} \mathrm{d} Q \\
\mathrm{DP}=\frac{\left(Q-Q^{*}\right)\left(-2 f\left(\alpha_{1}+\alpha_{2}\right)+\left(\alpha_{1} \alpha_{2}+g\left(\alpha_{1}+\alpha_{2}\right)\right)\left(Q+Q^{*}\right)\right)}{2\left(\alpha_{1}+\alpha_{2}\right)} .
\end{gathered}
$$

Substituting (20) into 25) and deriving by $Q$ yields the marginal damage caused by moving away from $Q^{*}$

$$
\mathrm{MDP}=+Q\left(g+\frac{\alpha_{1} \alpha_{2}}{\alpha_{1}+\alpha_{2}}\right)-f .
$$


Equating MDM and MDP and resolving for $Q$ yields the second best ammount of $Q$ where the negative effects of market power and from the deviation from the social optimal $Q^{*}$ are balanced

$$
\bar{Q}^{*}=\frac{f\left(\alpha_{1}+2 \alpha_{2}\right)^{2}+\left(\left(q_{01}+q_{02}\right) \alpha_{1}+\left(a_{1}+q_{02}\right) \alpha_{2}\right)\left(\alpha_{1}^{2}+3 \alpha_{1} \alpha_{2}+3 \alpha_{2}^{2}\right)}{\alpha_{1}^{3}+6 \alpha_{1}^{2} \alpha_{2}+13 \alpha_{1} \alpha_{2}^{2}+9 \alpha_{2}^{3}+g\left(\alpha_{1}+2 \alpha_{2}\right)^{2}} .
$$

If the government is unable or unwilling to $a_{1}=q_{1}^{*}$ (handing out full allocation to the dominant firm) as a countermeasure to market power, it may alternatively vary $Q$ according to (27) to obtain a second best social optimum.

\section{Conclusion}

Hahn [6] and others have stated that the only way to neutralize the negative consequences of market power on permit markets is to freely allocate an amount of permit to the firm with market power that coincides with the amount of emissions it chooses in (a partial) equilibrium. This paper does not contradict the findings by Hahn [6] and the related literature but augments the discussion.

In this paper it was shown that apart of choosing the allocation, choosing abatement costs, unrestricted emissions, or the cap on emissions can lead to situations where the firm with market power is impeded from exerting its power. While abatement costs or unrestricted emissions cannot be chosen externally in practice, the government might be able to change the cap on emissions. As Baumol \& Oates [1] have argued, environmental targets (i.e. the cap) are often chosen based on 'standards' which are seen as appropriate but '[...] will not, in general, result in an optimal allocation of resources' in a pareto efficient sense. If the cap would have been set as 'standard', varying the cap could be an option to improve the standard given the existence of market power.

If an optimal allocation in a pareto efficient manner shall be achieved, varying the cap (i.e. moving away from the social optimum) will decrease social welfare. However, if the government is unable to change a predetermined number of freely allocated permits so that market power is eliminated it will lead to a second best situation where adjusting the cap could increase welfare. By balancing the negative impact from changing the cap to a second best one and the positive effect of confining market power, adjusting the cap could increase the overall efficiency of environmental regulation under market power. 


\section{References}

[1] Baumol, William J., \& Oates, Wallace E. 1971. The use of standards and prices for protection of the environment. The Swedish Journal of Economics, 73(1), 42-54.

[2] Bovenberg, A Lans, \& Goulder, Lawrence H. 2000. Neutralizing the Adverse Industry Impacts of CO2 Abatement Policies: What Does It Cost? RFF Discussion Paper, 00-27(Washington D.C.).

[3] Goulder, Lawrence H., \& Parry, I. W. H. 2008. Instrument Choice in Environmental Policy. Review of Environmental Economics and Policy, 2(2), 152-174.

[4] Goulder, Lawrence H., Parry, Ian W. H., \& Burtraw, Dallas. 1997. Revenue-Raising versus Other Approaches to Environmental Protection: The Critical Significance of Preexisting Tax Distortions. The RAND Journal of Economics, 28(4), 708.

[5] Grubb, Michael, \& Neuhoff, Karsten. 2006. Allocation and competitiveness in the EU emissions trading scheme: policy overview. Climate Policy, 6(1), 7-30.

[6] Hahn, Robert W. 1984. Market power and transferable property rights. The Quarterly Journal of Economics, 99(4), 753-765.

[7] Heindl, Peter. 2012. Transaction Costs and Tradable Permits: Empirical Evidence from the EU Emissions Trading Scheme. ZEW Discussion Paper, 12-021(Mannheim).

[8] Hepburn, Cameron, Grubb, Michael, Neuhoff, Karsten, Matthes, Felix, \& Tse, Maximilien. 2006. Auctioning of EU ETS phase II allowances: how and why? Climate Policy, 6(1), 137-160.

[9] Hintermann, Beat. 2010. Market Power, Permit Allocation and Efficiency in Emission Permit Markets. Environmental and Resource Economics, 49(3), 327-349.

[10] Malik, Arun S. 2002. Further Results on Permit Markets with Market Power and Cheating. Journal of Environmental Economics and Management, 44(3), 371-390.

[11] Mandell, Svante. 2008. Optimal mix of emissions taxes and cap-and-trade. Journal of Environmental Economics and Management, 56, 131-140.

[12] Neuhoff, Karsten, Ahman, Markus, Betz, Regina, Cludius, Johanna, Ferrario, Federico, Holmgren, Kristina, Pal, Gabriella, Grubb, Michael, Matthes, Felix, Rogge, Karoline, Sato, Misato, Schleich, Joachim, Sijm, Jos, Tuerk, Andreas, Kettner, Claudia, \& Walker, Neil. 2006. Implications of announced phase II national allocation plans for the EU ETS. Climate Policy, 6(4), 411-422.

[13] Parry, I. W. H. 2003. Fiscal Interactions and the Case for Carbon Taxes Over Grandfathered Carbon Permits. Oxford Review of Economic Policy, 19(3), 385-399.

[14] Sinn, Hans-Werner, \& Schmoltzi, Ulrich. 1981. Eigentumsrechte, Kompensationsregeln und Marktmacht: Anmerkungen zum Coase Theorem. Jahrbuecher für Nationalökonomie und Statistik, 196(2), 97-117.

[15] Stavins, Robert N. 1995. Transaction Costs and Tradeable Permits. Journal of Environmental Economics and Management, 29(2), 133-148.

[16] Vollebergh, Herman R.J., De Vries, Jan L, \& Koutstaal, Paul R. 1997. Hybrid Carbon Incentive Mechanisms and Political Acceptability. Environmental and Resource Economics, 9, 43-63. 